\title{
Nodal metastases in non-small cell lung cancer: Hop, skip, or jump?
}

\author{
Valerie W. Rusch, MD
}

See related article on pages 790-5.

For several decades, there has been controversy about the impact of so-called "skip metastases" on overall survival in patients undergoing resection of non-small cell lung cancer (NSCLC). Generally defined as N2 (ipsilateral mediastinal) in the absence of N1 (bronchopulmonary or hilar) lymph node metastases, skip metastases have been reported to occur in a small subset of patients with stage IIIa NSCLC and to be associated with a more favorable outcome. ${ }^{1-4}$ Such skip metastases most frequently occur along anatomic patterns of preferential lymphatic drainage originally described by Riquet and colleagues, ${ }^{5}$ namely, in the aortopulmonary region nodes (levels 5 and 6) for left upper tumors and the right paratracheal nodes (right level 4) for right upper lobe cancers. Although repeatedly identified in retrospective series as a better prognostic group, NSCLC with skip metastases are still not classified separately in the current lung cancer staging system.

In this issue of the Journal, $\mathrm{Li}$ and colleagues ${ }^{6}$ again tackle the subject of skip metastases with the aim of defining whether these are indeed associated with a better prognosis than the more common progression of tumor "hop" from lung to N1, then N2 nodes, and what may be the pathologic and molecular factors associated with skip metastases. Starting with a group of 1139 patients who underwent surgery for NSCLC from 2009 to 2011, $\mathrm{Li}$ and colleagues focus this retrospective analysis on 177 patients who had N2 disease, 45 (25\%) of whom had skip metastases. They confirm that the patients with skip metastases had a significantly better 5 -year overall survival and find that skip N2 disease was associated with adenocarcinoma histologic subtype, tumor differentiation, and absence of lymphovascular invasion, but not with any of the common driver mutations currently known to occur in lung adenocarcinoma.

\footnotetext{
From the Department of Surgery, Memorial Sloan-Kettering Cancer Center, New York, NY.

Disclosures: Author has nothing to disclose with regard to commercial support.

Received for publication April 17, 2015; accepted for publication April 24, 2015; available ahead of print June 4, 2015.

Address for reprints: Valerie W. Rusch, MD, Department of Surgery, Memorial Sloan-Kettering Cancer Center, 1275 York Ave, New York, NY 10065 (E-mail: ruschv@mskcc.org).

J Thorac Cardiovasc Surg 2015;150:765-6

$0022-5223 / \$ 36.00$

Copyright (c) 2015 by The American Association for Thoracic Surgery http://dx.doi.org/10.1016/j.jtcvs.2015.04.051
}

This nicely performed study adds to the evidence that NSCLC with skip metastases is a distinct subset of stage IIIa disease. Consideration was given to separating these out into a separate category when the lung cancer staging system was revised several years ago, ${ }^{7}$ but the relatively small numbers of patients in this cate-

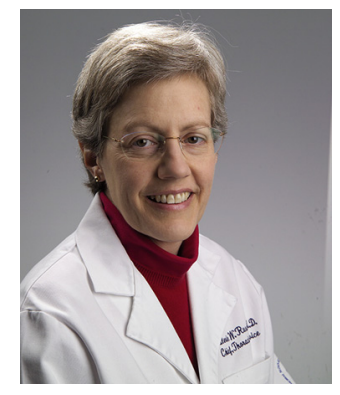
gory, even within the large lung cancer database developed by the International Association for the Study of Lung Cancer, make it hard to prove that this is appropriate statistically. It is also unclear whether such patients have a better outcome simply because of the low burden of metastatic disease (ie, single-level N2 nodal involvement) or because skip metastases represent an inherently different process of disease progression. Of these various patterns of nodal disease, which is biologically most likely to lead to the "jump" to more widely disseminated systemic cancer and cancer-related mortality?

Perhaps the most interesting aspect of the study by $\mathrm{Li}$ and colleagues ${ }^{6}$ is the novel observation that skip metastases seem to correlate with the acinar histologic subtype of lung adenocarcinoma. In the new histologic classification for adenocarcinoma, ${ }^{8}$ papillary and acinar-predominant adenocarcinomas seem to be associated with similar outcomes. However, it is suggested that there may be some important differences between these 2 subtypes. This is certainly hypothesis-generating and merits further investigation. No correlation was seen between skip metastases and known common lung adenocarcinoma driver mutations. Given the relatively small numbers of patients available for these analyses, $\mathrm{Li}$ and colleagues' results cannot be considered definitive. In this era of increasingly highthroughput molecular medicine, future, much larger-scale analyses are needed to prove or refute these initial results.

$\mathrm{Li}$ and colleagues ${ }^{6}$ present an excellent clinicalpathologic study on an important issue in the management of stage IIIa NSCLC and report some intriguing new findings that should prompt others to investigate the underlying biology of skip metastases.

\section{References}

1. Patterson GA, Piazza D, Pearson FG, Todd TR, Ginsberg RJ, Goldberg M, et al Significance of metastatic disease in subaortic lymph nodes. Ann Thorac Surg. 1987; 43:155-9.

2. Tateishi M, Fukuyama Y, Hamatake M, Kohdono S, Ishida T, Sugimachi K. Skip mediastinal lymph node metastasis in non-small cell lung cancer. J Clin Oncol. 1994;57:139-42. 
3. Riquet M, Assouad J, Bagan P, Foucault C, Le Pimpec-Barthes F, Dujon A, et al. Skip mediastinal lymph node metastasis and lung cancer: a particular N2 subgroup with a better prognosis. Ann Thorac Surg. 2005; 79:225-33.

4. Benoit L, Anusca A, Ortega-Deballon P, Cheynel N, Bernard A, Favre JP. Analysis of risk factors for skip lymphatic metastasis and their prognostic value in operated N2 non-small cell lung carcinoma. Eur J Surg Oncol. 2006:32:583-7.

5. Riquet M, Hidden G, Debesse B. Direct lymphatic drainage of lung segments to the mediastinal nodes. An anatomic study on 260 adults. J Thorac Cardiovasc Surg. 1989;97:623-32.
6. Li H, Hu H, Wang R, Li Y, Shen L, Sun Y, et al. Lung adenocarcinoma: are skip N2 metastases different from non-skip? J Thorac Cardiovasc Surg. 2015; 150:790-5.

7. Rusch VW, Crowley J, Giroux DJ, Goldstraw P, Im JG, Tsuboi M, et al. The IASLC Lung Cancer Staging Project: proposals for the revision of the N descriptors in the forthcoming seventh edition of the TNM classification for lung cancer. $J$ Thorac Oncol. 2007;2:603-12.

8. Travis WD, Brambilla E, Noguchi M, Nicholson AG, Geisinger KR, Yatabe Y, et al. International Association for the Study of Lung Cancer/American Thoracic Society/European Respiratory Society international multidisciplinary classification of lung adenocarcinoma. J Thorac Oncol. 2011;6:244-85.

Access to The Journal of Thoracic and Cardiovascular Surgery Online is reserved for print subscribers!

Full-text access to The Journal of Thoracic and Cardiovascular Surgery Online is available for all print subscribers. To activate your individual online subscription, please visit The Journal of Thoracic and Cardiovascular Surgery Online, point your browser to http://www.mosby.com/itcvs, follow the prompts to activate your online access, and follow the instructions. To activate your account, you will need your subscriber account number, which you can find on your mailing label (note: the number of digits in your subscriber account number varies from 6 to 10 ). See the example below in which the subscriber account number has been circled:

\section{Sample mailing label}

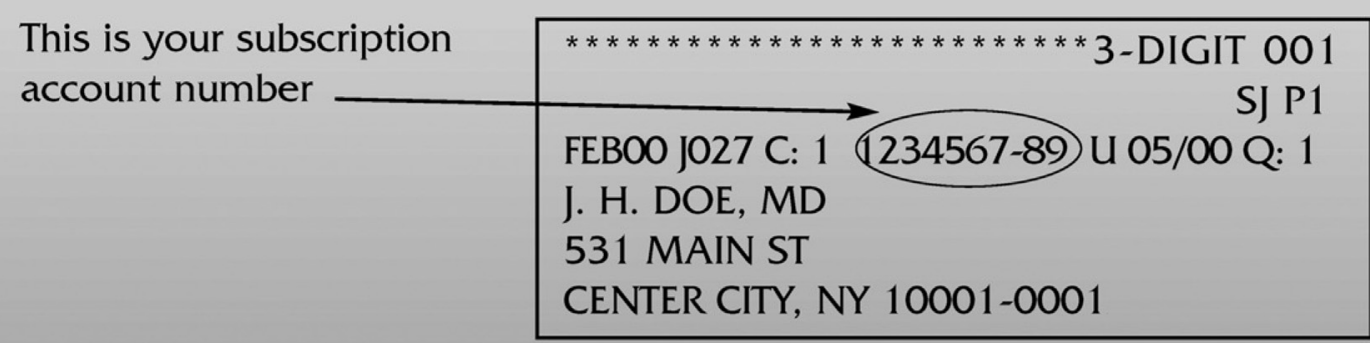

Personal subscriptions to The Journal of Thoracic and Cardiovascular Surgery Online are for individual use only and may not be transferred. Use of The Journal of Thoracic and Cardiovascular Surgery Online is subject to agreement to the terms and conditions as indicated online. 